\title{
Pemakaian Partikel kah dalam Kalimat Tanya
}

\author{
Ary Setyadi \\ Fakultas Ilmu Budaya, UniversitasDiponegoro \\ mr.arysetyadi@gmail.com
}

\begin{abstract}
Particle as a marker of the sentence type has its own characteristics/characteristics, namely: enclitis, human, and relatively free distributed. Due to the nature/ characteristics of the particle has a function as a confirmation of the sentence. In addition to the subject, the particles also have the ability to move in accordance with the elements of the sentence to be affirmed; and as a result of the ability to move in place the absence of particles can be able to join the many kinds of word classes. The application of methods, both data collection methods and methods of classification and data analysis as imposed in linguistic research activities. Namely: the stage of data collection, classification and data analysis phase, and stage of presentation/ report writing. The theory used in relation to the study of these particles is the linguistic theory of the syntactic field. The result show that the kah particle always follow to the word. Kah particle can be remove according to the sentence elements that are focused. The existing of kah particle in the interrogative sentence is optionally.
\end{abstract}

Keywords: particle, function, properties/character, location distribution, word class.

\section{Intisari}

Partikel kah sebagai penanda tipe kalimat tanya mempunyai sifat/ciri khusus, yaitu: bersifat enklitis, manasuka, dan relatif berdistribusi bebas. Akibat sifat/ciri tersebut maka partikel tersebut mempunyai fungsi sebagai penegas kalimat. Di samping perihal tersebut, partikel kah juga mempunyai kemampuan berpindah letak sesuai dengan unsur bagian kalimat yang hendak ditegaskan; dan akibat kemampuan berpindah tempat maka kebaradaan partikel kah mampu bergabung dengan sekian banyak macam kelas kata. Adapun penerapan metode, baik metode pengumpulan data maupun metode klasifikasi dan analisis data sebagaimana yang diberlakukan dalam kegiatan penelitian linguistik. Yaitu: tahap pengumpulan data, tahap klasifikasi dan analisis data, dan tahap penyajian/penulisan laporan. Teori yang digunakan sehubungan pengkajian partikel kah iniadalah teori linguistik bidang sintaksis. Hasil penelitian menunjukkan bahwa partikel kah selalu menempel pada kata. Partikel kah dapat berpindah letak sesuai dengan unsur kalimat yang dijadikan pemfokusan. Kehadiran partikel kah dalam kalimat tanya tidak bersifat wajib. Kata Kunci: partikel, fungsi, sifat/ciri, distribusi letak, kelas kata.

\section{Pendahuluan}

Macam partikel dalam dua sumber, misalnyaTata Bahasa Baku Bahasa Indonesia (Moeliono (Ed.), 1988: 247) dan Kamus Besar Bahasa Indonesia (2001: 831) dikatakan mencakup: lah, kah, tah, pun. Di antara empat macam bentuk tersebut, partikel kah dan 
lahmenunjukkan berfrekuensi pemakaian yang relatif tinggi,jika dibanding dengan yang lain, yaitu: tah dan pun (Setyadi, 1987: 234-245).

Pernyataan semacam berlaku wajar sebab kehadiran partikel kah, di samping secara dominan sebagai penanda tipe kalimat tanya/imperatif, ternyata dapat juga dijumpai dalam di tipe kalimat berita/deklaratif. Kehadiran partikel kah dalam kalimat -- khususnya dalam tipe kalimat tanya-berdasarkan dataternyata menampakkan persoalan: 1. sifat/ciri danfungsi, 2.ketentuan letak, dan 3. kemampuan bergabung dengan macam kelas kata/kategori, sehingga menarik dikaji. Sebab ternyata ketiga persoalanyang adabelum mendapat perhatian secara khusus dan mendalam. Dengan demikian ketigapersoalan yang ada merupakan tujuan yang hendak dicapai.

\section{Metode Penelitian}

Pelaksanaan penelitian mendasarkan pada tiga tahap yaitu: tahappenyediaan data;tahapklasifikasi dan analisis data; dan tahap penyajian hasil analisis (Sudaryanto, 1982: 11-18). Tahap pertama, yaitu tahap penyediaan data. Pada tahap ini mendasarkan pada "metode penyimakan", baik simak baca maupun simak dengar dengan penerapan teknik pencatatan dalam kartu data. Penerapan teknik simak dengar menghasil data primer, sedang dari penerapan teknik simak baca menghasilkan data sekunder. Dengan demikian sumber data bertolak pada sumber data, baik sumber data lisan maupun sumber data tulis.

Tahap kedua, yaitu tahap klasifikasi dan analisis data. Klasifikasi data mendasarkan pada: sifat/ciri dan fungsi, ketentuan letak, dan kemampuan daya gabung partikel kah dengan kelas kata/kategori kata. Dengan demikian penerapan metode atas ketiga persoalan mendasarkan pada metode distribusional dengan memanfaatkan teknik analisis: penggantian, perluasan, penyisipan, permutasi, dan teknik parafrasa. Adapun teori yang digunakan sehubungan pembahasan ketiga persoalan yang ada adalah teori linguistik (struktural) sebagaimanadalam bukuTata Kalimat Bahasa Indonesia (Samsuri, 1985: 447). Tahap ketiga, yaitu tahap penyajian. Tahap ketiga merupakan tahap akhir kegiatan, sebab telah berkait dengan upaya penyusunan laporan penelitian, Pada tahap ini berakhir dengan dapat disusunnya sebuah laporan berbentuk sebuah artikel ini.

\section{Pembahasan}

Sajian berikut di bawah ini berkait dengan peupaya tinjauan (ke)pustaka(an) demi pembuktian bahwa ketiga persoalan partikel kah dalam tipe kalimat tanya belum dibahas secara tersendri dan mendalam dari beberapa sumber bacaan. 
Partikel kah dalam Kamus Besar Bahasa Indonesia (2001: 831) hanya disinggung secara sekilas saja. Yaitu bahwa apa yang disebut dengan partikel mencakup: artikel, preposisi, konjungsi, dan interjeksi. Partikel, termasuk partikel kah, dijelaskan hanya mempunyai makna gramatikal saja, dan tidak mempunyai makna leksikal; serta tidak dapat diderivikasikan atau diinfleksikan.

Buku Tata Bahasa Baku Bahasa Indonesia menyingung juga masalah partikel kah(Moeliono (Ed.), 1988: 247). Sajian bahasan partikel dijelaskan sebagai kelompok kata tugas, dan dikatakan berupa klitika. Macam partikel mencakup: -kah, -lah, pun, dan -tah.

Khusus bahasan partikel -kah hanya dijelaskan bersifat manasuka dan kadangkadang wajib; bergantung dari macam kalimatnya, dan kehadirannya memberi sifat formal kalimat dan sedikit memperhalus ucapan kalimat. Partikel -kah dapat dijumpai pada kalimat tanya maupun kalimat berita (bergantung pengucapannya).

Dalam buku Ilmu Bahasa Indonesia: Sintaksis (Ramlan, 1981: 12) hanya menyoal bahwa bentuk kah, yaitudisebut sebagai kata dan dapat ditambahkan pada kalimat tanya; kecuali pada S(ubjek), dan bercenderung diletakkan pada bagian kalimat yang ditanyakan di awal kalimat. Sumber lain Imperatif dalam Bahasa Indonesia (Rahardi, 2000: 75) -kah disebut sebagai partikel, dan hanya dijelaskan: bahwa keberadaannya dapat ditambahkan pada kata apa sebagai pemerhalus atau penanda kesantunan.

Pembahasan partikel kah juga dapat dijumpai dalam buku tata bahasa sebelum tahun70an, atau sering disebut/digolongkan sebagai tata bahasa Tradisional (Ramlan, 1979), misalnya:(Mees, 1953), (Hadidaja, 1963), Lubis (1954), Pudjawijatna dan P.J. Zoetmulder (1955), Alisjahbana (1974). Sajian bahasan hanya terbatas pada contoh sebagaimanadalam bentuk kata apakah. Berdasarkan beberapa sumber bacaan di atas, tampak jelas bahwa keberadaan partikel kah, khususnya dalam tipe kalimat tanya, belum dibahas secara khusus dan mendalam. Sajian pembahasan bermula dari permasalahan tipe kalimat tanyasendiri sendiri, sebab frekuensi kemunculan partikel kah sering dijumpai sehingga keberadaannya dapat dikatakan sebagai salah satu penanda.

\section{Kalimat Tanya}

Salah satutipe kalimat yang memerlukan respon (tindakan, jawaban) dari lawan bicara $(\mathrm{O} 2) /$ petutur/mitra tutur adalah kalimat tanya. Sebab apa yang disebut dengan kalimat tanya adalah, "Kalimat yang mengandung maksud menanyakan sesuatu kepada mitra tutur.” (Rahardi, 2000: 75. Bandingkan Ramlan, 1981: 12). 
Lebih lanjut dijelaskan, bahwa tipe kalimat tanya dibedakan menjadi lima macam cara pembentukannya, yaitu: 1. dengan membalikkan urutan kalimat, 2. dengan menggunakan kata apa atau apakah, 3. Dengan menggunakan kata bukan atau tidak, 4. dengan mengubah intonasi kalimat, dari kalimat berita ke pola intonasi kalimat tanya, dan 5. dengan menggunakan kata-kata tertentu.

Berdasarkan kelima proses pembentukan tersebut, ternyata tipe kalimattanya hanya dapat dibedakan menjadi dua, yaitu: 1. kalimat tanya total, dan 2. kalimat tanya parsial. Beda kedua macam tipe kalimat tanya yang dimaksud adalah: tipe kalimat tanya total memerlukan jawaban "Ya"/ "Tidak", sedang tipe kalimat tanya parsial memerlukan jawaban "menjelaskan tentang sesuatu" (sebagaimana yang isi tujuan kalimat).

Dua macamtipe kalimat tanya semacam di atas sejalan dengan pendapat Ramlan (1981: 14) yang disebut dengan istilah: 1. kalimat tanya yang memerlukan jawab "Ya" atau "Tidak", dan 2. kalimat tanya yang memerlukan jawaban memberi penjelasan. Tipe kalimat yang memerlukan jawaban "Ya" atau "Tidak" itulah yang disebut dengan tipe kalimat total; sedang kalimat tanya yang memerlukan jawaban "menjelaskan", itulah yang disebut dengan tipe kalimat tanya parsial.

Penggolongan dua macam kalimat tanya tersebut berdasarkan respon jawaban dari petutur $(\mathrm{O} 2)$, dan termasuk juga macam kalimat tanya retoris. Yaitu kalimat tanya yang ditujukan kepada pihak petutur (O2), tetapi pihak penutur (O1) tidak mengingini jawaban. Sebab pihak penutur (O1) telah mengetahui isi jawaban atas pertanyaaan (Keraf, 1977: 39).

Berdasarkan ketiga macam tipe kalimat tanya di atas, yaitu: 1. tipe kalimat total, 2. tipe kalimat parsial, dan 3. tipe kalimat retoris, partikel kah ternyata dengan mudah dijumpai sebagaimana contoh berikut.

(1) Apakah murid-murid masih belajar di kelas?

(2) Terdiri dari berapa proseskah pengolahan tempe itu?

(3) Masih maukah kita dijajah oleh Belanda kembali?

Ketiga data di atas memberikan contoh: data (1) adalah contoh tipe kalimat tanya total, data (2) adalah contoh tipe kalimat tanya parsial, dan data (3) adalah contoh tipe kalimat tanya retoris.

Bertolak dari ketiga data di atas, akhirnya dapat dianalisis permasalahan yang berkait dengan: 1. sifat/ciri dan fungsi partikel kah, 2. ketentuan letak partikel kah, dan 3 . kemampuan daya gabung partikel kah dengan macam/jenis kelas kata/prakategorial sebagaimana sajian di bawah ini. 


\section{Sifat/Ciri dan Fungsi Partikel kah}

Analisis sifat/ciri dan fungsi partikel kah bermula dari sajian dasar analisis penentuan alasan kepastian perbedaan antara partikel dengan afiks sebagaimana contoh berikut.

(4) Haruskahaku yang datang ke sana?

(5) Semua peristiwa hidup kucatat dalam buku harian.

Kehadiran kah dan -an dalam haruskah dan harian menampakkan kesamaan, yaitu keduanya sama-sama melekat pada kata yang diikutinya. Keduanya bersifat enklitis, sehingga sifat atau ciri partikel kah dapat dikatakan sama dengan dengan akhiran -an.

Pembuktian sifat/ciri yang lain dapat dijelaskan pada perubahan data (4) menjadi (4a dan 4b), begitu pula data (5) diubah menjadi (5a dan 5b).

(4a) Harus aku yang datang ke sanakah?

(4b) Harus(...) aku yang datang ke sana?

(5a) *Semua peristiwa hidup kucatat dalam bukuan hari.

(5b) *Semua peristiwa hidup kucatat dalam buku hari(...).

Berdasarkan data tersebuttampak jelas bahwa kehadiran partikel kah bersifat/berciri relatif bebas. Berbeda dengan akhiran-an.

Data (4b) partikel kah dapat dikatakan bersifat/berciri manasuka, lain halnya dengan kehadiran akhiran-andalam data (5b) bersifat wajib.

Berdasarkan sifat/ciri partikel kahyang: enklitis, relatif bebas, dan manasuka tersebut, ternyata kehadirannyadapatberfungsi sebagai penegas/penekanan/intensitas, dan bahkan dari sebuah sumber dikatakan sebagai pemfokusan kalimat (Samsuri, 1985: 445). Bukti bahwa kehadiran partikel kah mempunyai fungsi sebagaimana yang dimaksud dapat dilihat pada data (4), yang dapat diubah menjadi (4a). Kehadiran kah pada data (4) memberi penegasan/penekanan/intensitas pada kata harus, sedang kehadiran partikel kah dalam data (4a) memberi penegasan/penekanan/intensitas pada kata sana. Sifat/ciri partikel kah yang: enklitis, relatif bebas, dan manasuka dapat disejajarkan dengan sifat/ciri partikel lah dalam tipe kalimat perintah/imperatif (Setyadi, 1987: 234-245).

\section{Ketentuan Letak Partikel kah}

Pembuktian bahwa kehadiran partikel $k a h$ atas dasar ketentuan letak dalam kalimat memberi penegasan/penekanan/intensitas unsur fungsi kalimat bertolak pada pendapat yang mengatakan, "Kalimat yang berpredikat verba yang bukan pasif dapat dibedakam menjadi empat macam: (1) kalimat taktransitif, (2) kalimat ekatransitif, (3) kalimat 
dwitransitif, dan (4a) kalimat semitransitif (Moeliono (Ed.), 1988: 271). Bertolak dari pendapat tersebut, akhirnya dapat dijelaskan ketentuan letak partikel kah dalam kalimat sebagaimana sajian bahasan berikut.

Menurut Ramlan (1981: 63) bahwa unsur fungsi kalimat (klausa bebas) mencakup: S(ubjek), P(redikat), O(bjek), PEL(engkap), dan KET(erangan). Kelima unsur fungsi kalimat tersebut menjadi fokus analisis dengan mendasarkan pada keempat macam kalimat di atas.

\section{Kalimat Taktransitif}

Secara fungsional apa yang disebut dengan kalimat taktransitif diisi oleh inti unsur fungsi S-P sebagaimana contoh berikut.

(6) Ibu sedang bersolek.

Data (6) dapat diubah menjadi kalimat tanya, misalnya sebagai berikut.

(6a) Ibu sedang bersolek?

(6b) Ibu sedang bersolekkah?

Berdasarkan data (6b) tampak jelas bahwa kehadirankah berfungsi sebagai penegas/penekan/intensitas unsur fungsi $\mathrm{P}$ (redikat), dan kehadirannya dapat disejajarkan dengan upaya pemfokusan (bagian kalimat).

Perlu dicatatkan di sini, bahwa upaya pemfokusan unsur fungsi kalimat tidak berlaku bagi unsur fungsi P(redikat).Sebab jika S(ubjek) kalimat diikuti partikel kah, makaterjadi perubahan fungsi sebagaimana data (6) diubah menjadi (6c).

(6c) *Ibukah sedang bersolek?

Perubahan akibat partikel kah bergabung dengan S(ubjek) kalimat mengisyaratkan bentuk (6c): ibukah sebagai P(redikat), sedang yang sedang bersolek sebagai S(ubjek).

(6d) Ibukah yang sedang bersolek?

Data (6c) menunjukkan bukti bahwa fungsi S(ubjek) tidak dapat difokuskan. S(ubjek) kalimat tidak dapat difokuskan. Pemfokusannya hanya dapat dilakukan dengan menggunakan bantuan intonasi (Samsuri, 1985: 423).

\section{Kalimat Ekatransitif}

Kalimat ekatransitif secara fungsional diisi oleh $\mathrm{S}$ (ubjek) - P(redikat) - O(bjek). Contoh:

(7) Adik sedang membaca buku.

Data (7) dapat diubah menjadi kalimat tanya sebagai berikut.

(7a) Adik sedang membaca buku?

(7b) Adik sedang membaca bukukah? 
Berdasarkan data (7b) tersebut tampak jelas bahwa partikel kah dapat bergabung dan menduduki ketentuan letak unsur fungsi O(bjek) kalimat.

\section{Kalimat Dwitransitif}

Berdasarkan unsur fungsional tipe kalimat dwitransitif terdiri atas urutan S(ubjek) $\mathrm{P}($ redikat $)$ - O(bjek) - PEL(engkap). Contoh:

(8) Kakak membacakan nenek surat.

Data (8) dapat diubah menjadi tipe kalimat tanya sebagai berikut.

(8a) Kakak membacakan nenek surat?

(8b) Kakak membacakan nenek suratkah?

Bertolak dari dari (8b) tampak jelas bahwa partikel kah dapat bergabung dengan kata yang mengisi unsur fungsi PEL(engkap) kalimat.

\section{Kalimat Semitransitif}

Unsur fungsi yang mengisi tipe kalimat semitransitif adalah: S(ubjek) - P(redikat) PEL(engkap). Contoh:

(9) Siti Halimah sedang belajar sejarah Indonesia.

Data (9) dapat diubah menjadi tipe kalimat tanya (9a,b). Bentuk data (9b) membuktikan adanya kemampuan partikel kah bergabung dengan kata pengisi unsur fungsi PEL(engkap).

(9a) Siti Halimah sedang belajar sejarah Indonesia?

(9b) Siti Halimah sedang belajar sejarah Indonesiakah?

Akibat unsur fungsi KET(erangan) relatif bersifat bebas letak dan manasuka (Ramlan, 1981: 70), maka kehadirannya dapat dijumpai dalam keempat macam tipe kalimat: taktransitif, ekatransitif, dwitransitif, dan semitransitif. Contoh:

(10) Bapak sedang tidur.

(11) Kakek menggambar sebuah boneka.

(12) Ibu Sabar memberi Ani uang.

(13) Paman berjualan bakmi.

Keempat data dapat diikuti unsur fungs KET(erangan), misalnya oleh kata/frasa $d i$ teras, sehingga menjadi

(10a) Bapak sedang tidur di teras.

(11a) Kakek menggambar sebuah boneka di teras.

(12a) Ibu Sabar memberi Ani uang di teras.

(13a) Paman berjualan bakmi di teras. 
Masing-masing data dapat diubah menjadi kalimat tanya dengan menambahkan partikel kah di kata/frasa di teras, sehingga data yang bersangkutan membuktikan bahwa unsur fungsi KET(erangan) dapat diikuti partikel $k a h$.

(10b) Bapak sedang tidur di teraskah?

(11b) Kakek menggambar sebuah bonekah di teraskah?

(12b) Ibu Sabar memberi Ani uang di teraskah?

(13b) Paman berjualan bakmi di teraskah?

\section{Kemampuan Daya Gabung}

Pengertian kemampuan daya gabung berkait dengan fakta kemampuan partikel kahdalam bergabung dengan kelas kata/kategori (kata). Yaitu bersumber buku Penggolongan Kelas Kata dalam Bahasa Indonesia (Ramlan, 1985: 48-75) dan Kelas Kata Bahasa Indonesia (Kridalaksana, 2007: 51-124).

Berdasarkan referensi tersebutakhirnya menghasilkan macam kelas kata/kategori (kata) yang mampu diikuti partikel kah: 1. kerja, 2. benda, 3. keterangan, 4. bilangan, 5. tanya, 6. ganti orang, 7. sifat, 8. penyukat, dan 9. kata tunjuk sebagaimana sajian berikut.

\section{Kata kerja+ kah}

Pengertian kata kerja adalah: kata yang dapat didahului oleh kata negatif tidak ..., dan/atau kata yang dapat diikuti frasa dengan sangat ... (Ramlan, 1985: 50). Contoh

(14) Ahmad masih berdiri sampai saat ini.

(15) Dia tidak tidur malam ini.

Salah satu unsur kata kedua kalimat di atas adalah berdiri dan tidur, yang berkategori (kata) kata kerja. Kedua kalimat dapat diubah menjadi kalimat tanya dengan mengubah intonasi dan/atau menambah partikel $\mathrm{kah}$.

(14a)Ahmad masih berdiri sampai saat ini?

(14b) Ahmad masih berdirikah sampai saatini?

(15a) Dia tidak tidur malam ini?

(15b) Dia tidak tidurkah malam ini?

\section{Kata Benda + kah}

Apa yang disebut dengan kata benda adalah: kata yang dapat dinegatifkan kata bukan dan dapat diikuti kata itu (Ramlan, 1985: 51). Contoh kah bergabung dengan kelas kata benda.

(16) Ia membawa buku hari ini.

(17) Hari ini, hari Selasa. 
Kedua data dapat diubah dengan: mengubah intonasi dan/atau menambahkan partikel kah pada kata buku dan selasa yang berkelas kata benda/nomina.

(16a) Ia membawa buku hari ini?

(17a) Hari ini, hari Selasa?

(16b) Ia membawa bukukah hari ini?

(17b) Hari ini, hari Selasakah?

\section{Kata Keterangan + kah}

Pengertain kata keterangan adalah: kata yang berkemungkinan menduduki unsur fungsi KET(erangan) dalam klausa, dan relatif bersifat bebas letak (di awal, tengah, maupun belakang) dalam satu konstruksi kalimat (Ramlan, 1985: 52-53)

Sajian di bawah ini membuktikan bahwa partikel kah dapat bergabung dengan kata yang berkelas kata keterangan. Contoh:

(18) Sekarang waktu yang tepat untuk pergi.

(19) Dia datang tadi.

Data $(18,19)$ dapat diubah menjadi tipa kalimat tanya, salah satunya dengan menambahkan partikel kah.

(18a) Sekarang waktu yang tepat untuk pergi?

(19a) Dia datang tadi?

(18b) Sekarangkah waktu yang tepat untuk pergi?

(19b) Dia datang tadikah?

\section{Kata Bilangan + Kah}

Kata bilangan/numeralia dapat dijelaskan, “...sejumlah kata yang dapat diikuti Kata-kata orang, ekor, buah, helai, kodi, meter, dan sebagainya" (Ramlan, 1985: 54).

Sajian data berikut membuktikan bahwa kehadiran partikel kah dapat bergabung dengan kelas kata bilangan/numeralia dalam tipe kalimat tanya.

(20) Rumah kedua yang akan dicat.

(21) Dia anak ketiga.

Kedua data dapat diubah menjadi kalimat tanya sebagai berikut.

(20a) Rumah kedua yang akan dicat?

(21a) Dia anak ketiga?

(20b) Rumah keduakah yang akan dicatat?

(21b) Dia anak ketigakah? 


\section{Kata Tanya + Kah}

Pengertian kata tanya/interogativa dapat dijelaskan, "Kata yang dipakai sebagai penanda pertanyaan dalam kalimat tanya (Kridalaksana, 2001: 100). Keberadaan kata tanya dapat diikuti partikel tanya sebagaimana contoh berikut.

(22) Apa dia hadir hari ini?

(23) Bila guru kita datang?

(22a) Apakah dia hadir hari ini?

(23a) Bilakah guru kita datang?

\section{Kata Ganti Orang + Kah}

Kata ganti orang/pronomina dapat dijelaskan, "Kata yang menggantikan nomina atau frase nomina." (Kridalaksana, 2001: 179). Persoalan nomina yang dimaksud berkait dengan kata seperti: saya, dia,kami, mereka.

Bukti bahwa partikel kah dapat bergabung dengan kata ganti orang/pronomina dapat dijelaskan dengan data berikut.

(24) Hanya kami yang disalahkan

(25) Kalian yang mengotori tempat ini.

(24a) Hanya kami yang disalahkan?

(25a) Kalian yang mengotori tempat ini?

(24b) Hanya kamikah yang disalahkan?

(25b) Kaliankah yang mengotori tempat ini?

\section{Kata Sifat + Kah}

Pengertian kata sifat/adjektiva dapat dijelaskan, "Kata yang menerangkan kata benda, ... mempunyai ciri dapat bergabung dengan tidak dan partikel seperti lebih, sangat, dsb." (Kridalaksana, 2001: 3).

Dua data berikut memberi bukti bahwa kehadiran partikel kah dapat bergabung dengan kata sifat/adjektiva dalam kalimat tanya.

(26) Dia adil terhadapmu.

(27) Dia sebegitu dendam terhadapmu.

(26a) Dia adil terhadapmu?

(27a) Dia sebegitu dendam terhadapmu?

(26b) Dia adilkah terhadapmu?

(27b) Dia sebegitu dendamkah terhadapmu? 


\section{Kata Tambah + Kah}

Kata tambah dapat dijelaskan, “... sejumlah kata yang cenderung hanya menduduki funsi atribut dalam frase yang termasuk tipe konstruksi endosentrik yang atributif,...” (Ramlan, 1985: 53).

Contoh kata tambah yang dapat diikuti partikel $k a h$ dalam kalimat tanya sebagaimana sajian berikut.

(28) Dia akan pergi dengannya hari ini.

(29) Kamu harus datang ke sana.

Jika kedua data tersebut diubah menjadi tipe kalimat tanya, maka akan menjadi:

(28a) Dia akan pergi dengannya hari ini?

(29a) Kamu harus datang ke sana?

(28b) Dia akankah pergi dengannya hari ini?

(29b) Kamu haruskah datang ke sana?

\section{Kata Penyukat + Kah}

Istilah lain dari kata penyukat adalah kata satuan, adapun pengertian kata penyukat dapat dijelaskan, "Kata yang terletak di belakang kata bilangan dan bersama-sama kata itu membentuk satu frase yang disebut frase bilangan, ...” (Ramlan, 1985: 55).

Bukti bahwa keberadaan kata penyukat dapat diikuti partikel kah dalamtanya dapat dilihat sajian daya berikut.

(30) Hanya tiga ekor bebek yang terlepas.

(31) Tinggal tujuh helai kain batik itu.

(30a) Hanya tiga ekor bebek yang terlepas?

(31a) Tinggal tujuh helai kain batik itu?

(30b) Hanya tiga ekorkah bebek yang terlepas?

(31b) Tinggal tujuh helaikah kain batik itu?

\section{Kata Tunjuk + Kah}

Kata tunjuk/demonstrativa dapat dijelaskan, "Kategori yang berfungsi untuk menunjukkan sesuatu di dalam maupun di luar wacana. Sesuatu itu disebut anteseden. ... seperti itu dan ini." (Kridalaksana, 2007: 92).

Bukti bahwa keberadaan kata tunjuk/demonstrativa dalam kalimat tanya dapat diikuti partikel kah dapat dilihat sajian data berikut.

(32) Ini sebuah rumah yang kaumaksud. 
(33) Itu orang yang pernah menggodamu.

(32a) Ini sebuah rumah yang kaumaksud?

(33a) Itu orang yang pernah menggodamu?

(32b) Inikah sebuah rumah yang kaumaksud?

(33b) Itukah orang yang pernah menggodamu?

\section{Simpulan}

Sifat/ciri enklitis $k a h$ terbukti dari keberadaannya yang selalu menempel/mengikuti pada kata, sebagaimana partikel pada umumnya, tidak mampu bersendiri dalam satu tuturan (terikat secara fonologis, tetapi relatif bebas secara gramatikal).Sifat/ciri yang relatif bebas terbukti dari kehadiran partikel kah dapat berpindah letak tempat sesuai dengan kebutuhan bagian unsur kalimat yang dijadikan pemfokusan.Berdasarkan sifat/ciri manasuka bahwa kehadiran partikel kah dalam kalimat tanya tidak bersifat wajib, meskipun di samping berpengaruh atas kendalan intonasi kalimat, ternyata juga relatif berpengaruh atas adanya kemungkinan pergeseran arti kalimat yang bersangkutan.

\section{Daftar Pustaka}

Alisjahbana, S. Takdir. 1974. Tata Bahasa Baru bahasa Indonesia. Jilid 1. Jakarta: Dian Rakyat.

Hadidjaja, Tardja, 1963. Tatabahasa Indonesia. Yogya: UP Indonesia.

Kamus Besar Bahasa Indonesia. 2001. Jakarta: Balai Pustaka.

Keraf, Gorys. 1977. Komposisi. Jakarta: Nusa Indah.

Kridalaksana, Harimurti. 2001. Kamus Linguistik. Jakarta: PT Gramedia Pustaka Utama. 2007. Kelas Kata dalam Bahasa Indonesia. Jakarta: PT Gramedia Pustaka.

Lubis, Madong. 1954. Paramasastera Landjut. Djakarta: Amsterdam Versluys.

Mees, C.A. 1953. Tatabahasa Indonesia. Bandung: G. Kolf \& CO

Moeliono, Anton M (Ed.). 1988. Tata Bahasa Baku Bahasa Indonesia. Jakarta: Perum Balai Pustaka.

Pudjawijatna dan P.J. Zoetmulder. 1955. Tatabahasa Indonesia, Djakarta: N.V. Obor.

Rahardi, Kunjana. 2000. Imperatif dalam Bahasa Indonesia. Yogyakarta: Duta Wacana University Press.

Ramlan, M. 1979. “Tradisi Tatabahasa Bahasa Indonesia hingga Tahun 70-an”. Pidato Pengukuhan Guru Besar dalam Ilmu Bahasa Indonesia. Fak. Sastra UGM, Yogyakarta.

1981. Ilmu Bahasa Indonesia: Sintaksis. Yogyakarta: UP Karyono. 
1985. Tata Bahasa Indonesia: Penggolongan Kata. Yogyakarta: Andi Offset.

Samsuri. 1985. Tata Kalimat Bahasa Indonesia. Jakarta: Erlangga.

Setyadi, Ary. 1987. "Watak" dan Peran Pemakaian Lah: Suatu Tinjuan Deskreptif Pemakaian Lah dalam Kalimat". Dalam Majalah Pembinaan Bahasa Indonesia. Th. 8 No. 4, Desember.

Sudaryanto.1982. Metode Linguistik. Yogyakarta: Fak Sastra dan Budaya UGM. 